\title{
Aplikácia RTLS systémov v skladových priestoroch
}

\author{
Peter Trebuňa ${ }^{1}$, Marek Mizerák ${ }^{1}$, Jozef Trojan ${ }^{1}$, Ján Kopec ${ }^{1}$ \\ 1 Technická univerzita, Strojnícka fakulta - Ústav priemyselného inžinierstva, manažmentu a \\ inžinierstva prostredia \\ Park Komenského 9, 04200 Košice, Slovensko \\ peter.trebuna@tuke.sk \\ marek.mizerak@tuke.sk \\ jozef.trojan@tuke.sk \\ jan.kopec@tuke.sk
}

\begin{abstract}
Abstrakt: Tento príspevok sa zaoberá problematikou priemyselnej lokalizácie, jej využitím $v$ praxi a následnou analýzou konkrétnych príkladov použitia v skladových priestoroch výrobných podnikov. Príspevok vysvetl'uje definíciu technológie RTLS, ako aj jej topológiu alebo hlavné časti. Využitie lokalizačných systémov RTLS zdôrazňuje dôležitost' konceptu Industry 4.0 v moderných výrobných spoločnostiach, kde $v$ dnešnej dobe narastá dôraz na zjednodušenie procesu, využitel'nosti skladových priestorov, skrátenie časov, úspory a $\mathrm{v}$ neposlednom rade na bezpečnost'.
\end{abstract}

\section{1 Úvod}

Väčšina vel'kých spoločností už dnes na zefektívnenie a inováciu výroby používa rôzne monitorovacie alebo inak povedané lokalizačné technológie. Mnoho podnikov si práve uvedomuje, že digitalizácia je neoddelitel'nou súčast'ou každej „inteligentnej továrne“. Vd’aka pokroku $v$ dnešných technológiách sa manažéri a zamestnanci môžu spol'ahnút' na „tichých pracovníkov" $v$ podobe rôznych lokalizačných technológií. Tieto technológie v spojení so softvérovou podporou spoločnosti šetria peniaze, skracujú dobu výroby, zaist'ujú bezpečnost' pracovníkov a vo všeobecnosti zvyšujú celkový pohl'ad na činnost' výrobnej spoločnosti.

\subsection{Definicia RTLS systému}

Z anglického „Real Time Location Systems“ (RTLS) sa týka akéhokolvek systému, ktorý presne určuje polohu položky alebo osoby. RTLS nie je špecifickým typom systému alebo technológie, ale skôr ciel'om, ktorý je možné dosiahnut' pomocou rôznych systémov lokalizácie a správy aktív. Dôležitým aspektom RTLS je čas, v ktorom sa monitorujú aktíva, a tieto údaje je možné použit' rôznymi spôsobmi v závislosti od aplikácie. Niektoré aplikácie napríklad potrebujú iba časové stopy, pretože majetok prechádza určitou oblast'ou, zatial' čo iné aplikácie RTLS vyžadujú ovela podrobnejšiu viditel'nost' a vyžadujú neustálu aktualizáciu časových údajov. Ideálny lokalizačný systém dokáže presne lokalizovat' $v$ reálnom čase, sledovat' a spravovat' aktíva, zásoby alebo l'udí a pomôct' spoločnostiam prijímat' 
informované rozhodnutia na základe zhromaždených údajov o polohe. Ďalej je možné povedat', že systém RTLS slúži nielen na identifikáciu tagu, ale aj na jeho lokalizáciu a sledovanie pohybu $v$ reálnom čase. Systém určí polohu pomocou malých zariadení umiestnené na nami monitorovaných objektoch, aktívne značky RFID. Technológia RTLS je určená predovšetkým na monitorovanie a určovanie polohy predmetov $v$ interiéri alebo $v$ exteriéri (priestory výrobnej spoločnosti a pod.). RTLS sa používa $v$ mnohých odvetviach so špecifickými aplikáciami, ako je sledovanie zamestnancov a sledovanie majetku. Tieto aplikácie sa nachádzajú vo výrobnom a t’ažobnom priemysle, ale sú najdôležitejšie v zdravotníctve.

Každý systém RTLS používa určitú infraštruktúru. Aby systém fungoval hladko a správne, musí byt' monitorovaná oblast' pokrytá bezdrôtovou siet'ou, aby každý štítok mal dostatočný signál. Každý aktívny štítok RFID v sieti potom nezávisle prenáša údaje $z$ tejto siete na server, kde sú údaje d'alej spracované. Poloha alebo trajektória pohybu značky sa vyhodnocuje prostredníctvom aplikácie. Štítky sú malé elektronické zariadenia, ktoré sú pripevnené $\mathrm{k}$ akémukol'vek predmetu alebo jednotlivcovi, ktoré je potrebné sledovat'. Značky slúžia ako vysielač a vysielacie záblesky, ktoré sú zachytené kotvami a odoslané na lokalizačný server na výpočet polôh značiek.

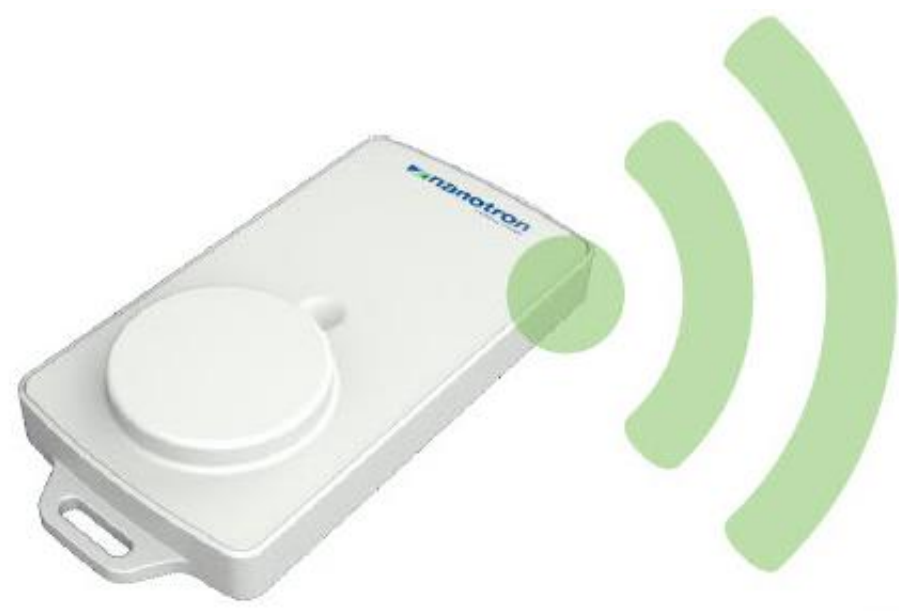

Obrázok 1 - Elektronický RTLS tag

Všetky aplikácie RTLS budú pozostávat' z niekol'kých základných komponentov: transpondéra, prijímača a softvéru na interpretáciu údajov $z$ každého z nich. Zložitost' systému, zvolená technológia a rozsah aplikácie určia množstvo hardvéru a softvéru potrebného na vytvorenie ideálneho RTLS.

\section{Využitie prvkov RTLS technologií v skladových priestoroch}

Zavedenie systémov RTLS do priemyselnej praxe kombinuje premyslenú kombináciu softvérovej a hardvérovej podpory. Spoločnosti zaoberajúce sa touto problematikou riešia aj problémy $v$ priemyselnej sfére. Monitorovanie sa zameriava na monitorovanie postavenia zamestnancov, ktoré má za úlohu 
chránit' zamestnancov zvýšením ich bezpečnosti, skrátením času potrebného na montážne a záchranné operácie, zvýšením bezpečnosti a zjednodušením zosúladenia pracovného času sumiestnením rôznych materiálov a polotovarov aj v spomínaných skladových priestorov výrobných podnikov.

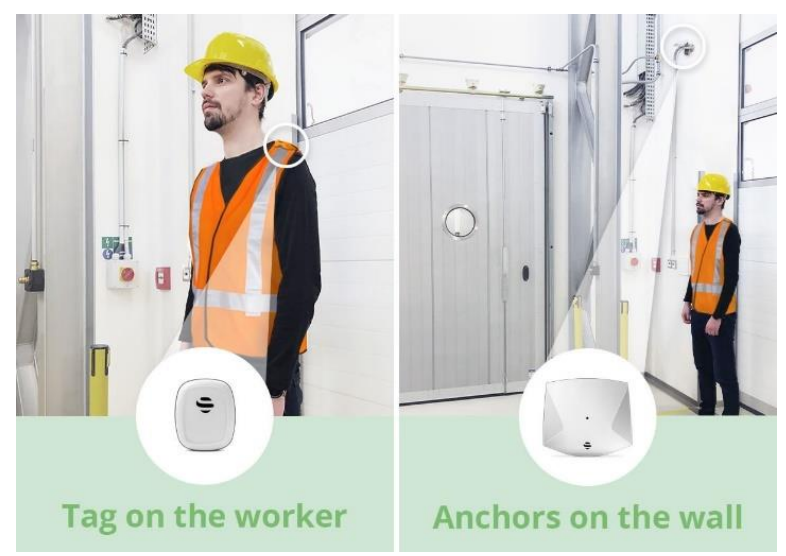

Obrázok 2 - Ochrana zamestnancov osobným tagom

Ďalšou aplikáciou je sledovanie vysokozdvižného vozíka. Táto aplikácia pomáha manažérom logistiky a výroby dosiahnut' väčšiu efektivitu, ziskovost' a bezpečnost' tým, že lepšie využíva flotilu, znižuje počet stratených hodín a, čo je dôležitejšie, prevenciu nehôd.
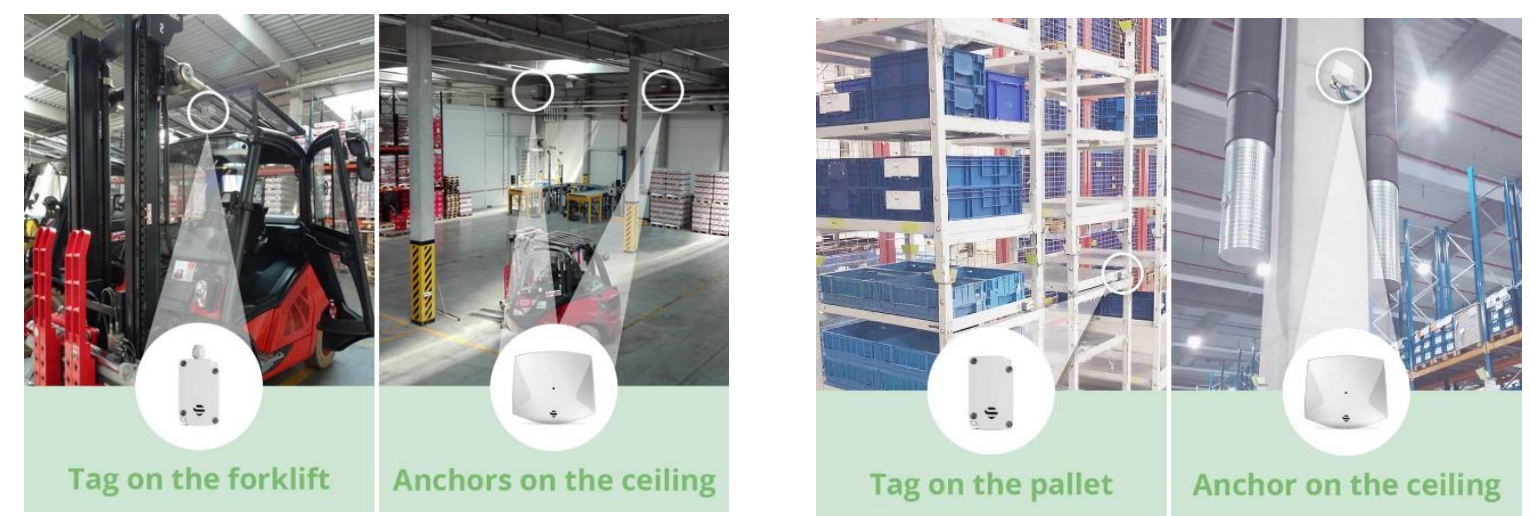

Obrázok 3 - Sledovanie vysokozdvižných vozíkov a majetku

Sledovanie majetku $v$ reálnom čase je proces sledovania fyzických aktív $v$ zariadení s ciel'om definovat' jeho polohu. Materiály alebo výrobky, ktoré sú monitorované s ciel'om monitorovat' ich tok počas výrobného procesu, môžu byt' tiež prínosom. Cielom sledovania majetku je maximalizovat' využitie majetku, zabránit' zneužitiu a optimalizovat' jeho úlohu vo všetkých procesoch. 
Zaujímavost'ou je eKanban pre analýzu materiálových tokov, ktorá vytvára prechod z manuálneho Kanbanu na eKanban (známy tiež ako Digital Kanban) pre bezpapierovú výrobu, je nevyhnutným krokom v digitálnej transformácii. Umožňuje väčšiu kontrolu nad prevádzkovým ziskom a peňažným tokom, zvyšuje efektivitu a produktivitu existujúcich zdrojov, eliminuje chyby a zlepšuje viditel'nost' a transparentnost' $v$ celej organizácii.

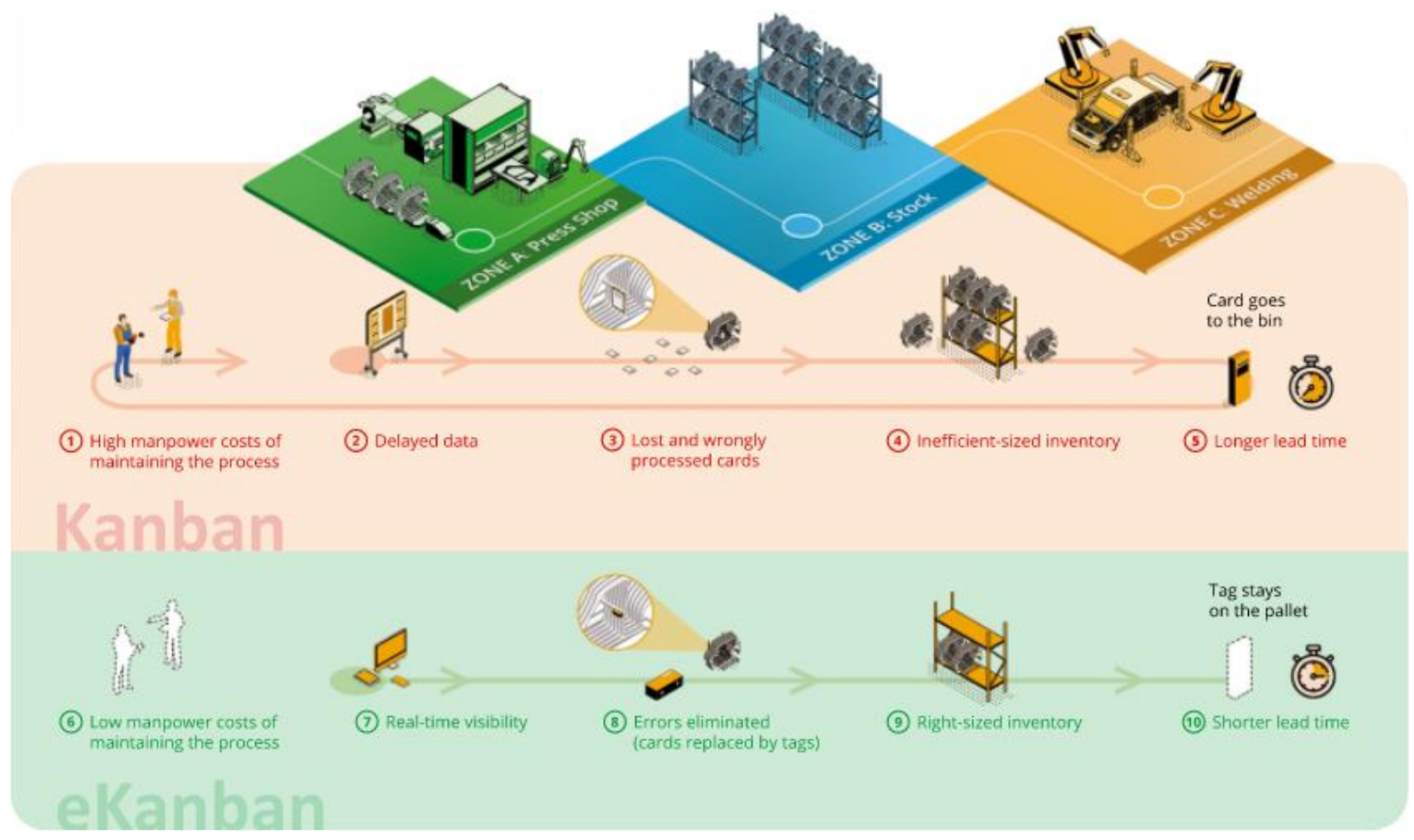

Obrázok 4 - Porovnanie Kanban vs eKanban

Aby sa skrátila doba dodania vo výrobnom procese například vo vzt'ahu sklad-výroba-sklad sú súčasné objednávky na papier nahradené digitálnymi objednávkami, ktoré obsahujú rovnaké informácie a rozširujú ich na umiestnenie $v$ reálnom čase a d'alšie typy údajov na základe použitých senzorov.

\section{Závěr}

Súčastné výrobné spoločnosti a závody podliehajú neustálej modernizácii, ktorá je zásadná pre úspech. Digitalizácia výrobných údajov pomocou prvkov priemyselnej lokalizácie, akými sú systémy RTLS, je stále viac uznávaná. Je to spôsobené výsledkami týchto systémov $v$ oblasti ochrany zdravia pracovníkov, ale hlavne za úsporu výrobných časov, ochranu majetku a produktov a $\mathrm{v}$ neposlednom rade za úsporu podnikových financií. $\mathrm{V}$ rámci týchto aplikácií je potrebné poukázat' na dôležitost' digitálnych dvojčiat, čo znamená „zrkadlenie“ fyzických klasifikácií a procesov, na základe ktorých je možné vizualizovat', hodnotit' a následne optimalizovat' využitie majetku ale aj zlepšovat' výroby. Vd'aka tejto skutočnosti získava priemyselná prax väčšiu 
kontrolu nad všetkým, čo sa deje vo výrobe, a tým zvyšuje efektivitu a produktivitu podnikania.

\section{Pod'akovanie}

Tento článok bol podporený projektmi:

VEGA 1/0438/20 Interakcia digitálnych technológií za účelom podpory softvérovej a hardvérovej komunikácie pokročilej platformy systému výroby

KEGA 001TUKE-4/2020 Modernizácia výučby priemyselného inžinierstva za účelom rozvoja zručností existujúceho vzdelávacieho programu $v$ špecializovanom laboratóriu

APVV-17-0258 Aplikácia prvkov digitálneho inžinierstva pri inovácii a optimalizácii produkčných tokov

APVV-19-0418 Inteligentné riešenia pre zvýšenie inovačnej schopnosti podnikov $v$ procese ich transformácie na inteligentné podniky

\section{Použitá literatúra}

[1] Digitálny podnik. [cit. 25/02/2016]. Available on the Internet: $<$ http://www.priemyselneinzinierstvo.sk/?page_id=1534>.

[2] GREGOR, M., MEDVECKÝ, Š., MIČIETA, B., MATUSZEK, J., HRČEKOVÁ, A., Digitální podnik. Žilina : Slovenské centrum produktivity, 2006. 80969391-5-7.

[3] EDL, M. - KUDRNA, J.: Metody průmyslového inženýrství. 1. vyd. Plzeň : Smart Motion, s.r.o., 2013, ISBN: 978-80-87539-40-8

[4] EDL, M.: Systémové pojetí životního cyklu technického projektu v prostředí DP. 1. vyd. Plzeň : Smart Motion, s.r.o., 2013, ISBN: 978-80-87539-20-0.

[5] FI'O, M. , MARKOVIČ, J. , IŽARÍKOVÁ, G. , TREBUŇA, P.: Geometric Transformations in the Design of Assembly Systems, 2013. In: American Journal of Mechanical Engineering. Vol. 1, no. 7 (2013), s. 434-437. - ISSN 2328-4110 Spôsob prístupu: http://www.sciepub.com/journal/ajme/Archive.

[6] Sewio Networks. Technology comparison. General information Dostupné na internete - $\quad$ https://www.sewio.net/uwb-technology/rtls-technologycomparison/Sewio

[7] Sewio Networks. RTLS in industry. General information Dostupné na internete - https://www.sewio.net/rtls-in-industry/ 